\title{
Lakes in Arid Land and Saline Dust Storms
}

\author{
Yongxiao Ge ${ }^{1,2}$, Jilili Abuduwaili ${ }^{1,2,3,}$, and Long $\mathrm{Ma}^{1,2,3}$ \\ ${ }^{1}$ State Key Laboratory of Desert and Oasis Ecology, Xinjiang Institute of Ecology and Geography, Chinese Academy of Sciences \\ Urumqi, 830011, P.R. China \\ ${ }^{2}$ CAS Research Centre for Ecology and Environment of Central Asia, Urumqi 830011, Xinjiang, P.R. China \\ ${ }^{3}$ University of Chinese Academy of Sciences, Beijing, 100049, P.R. China
}

\begin{abstract}
Saline dust storms are typical mainly for the arid and semiarid Central Asia induced by environmental change of tail-end lake basin. Although not the dominant type of global dust, saline dusts from playas may be important with respect to atmospheric chemistry, windborne nutrients and human health because of their high salt content. Saline dust storms in Central Asia occur frequently; this is not only a local issue, but also a regional ecological disaster. A complete understanding of the mechanism and diffusion characteristics are urgently required, and control measurements are urgently needed to lessen the occurrence of saline dust storms, which has been an ignored and serious environmental issue in the context of climate change in arid and semi-arid regions.
\end{abstract}

\section{Environmental changes of lakes in arid and semi-arid land}

Arid and semi-arid Central Asia maintains a fragile ecosystem that mainly consists of mountains, oases, and deserts. Rivers originate from the mountains after snow and ice melt, then dissipate and transform into oases, and finally travel into tail-end lakes in deserts, which form relatively independent hydrological systems. In arid and semi-arid regions, lakes are important to the hydrological cycle of regional water systems and play an important role in maintaining balance in the regional ecosystems. There are various types of lakes in arid Central Asia, which mainly lies in the central and west parts. Arid land of China is dotted within more than 700 lakes, mainly in Xinjiang. Kazakhstan has 48,262 lakes, of which 45,248 belong to a small area of less than $1 \mathrm{~km}^{2}$, accounting for $40 \%$ of the total area of the lake region. The total area of lakes in Tajikistan is about $1,005 \mathrm{~km}^{2}$, accounting for about $1 \%$ of the land area. Kyrgyzstan has 1,923 lakes, with a total area of $6,836 \mathrm{~km}^{2}[1]$.

However, surface temperature in Central Asia increased at an accelerating rate over the last century [24]. Climate change and unregulated human activities can easily cause undesirable transformations of the fragile ecosystems and disrupt the balance between human activities and natural processes, which could result in ecological disasters. Since second half of the 20th century, natural and anthropogenic factors have had a combined effect on lake water resources. Surface runoff is primarily used for irrigation or introduced into reservoirs, which have resulted in unpredictable negative dynamics in lakes that beyond safety thresholds and taillakes tend to shrink or dry out, which have seriously degraded the environment. In the past 30 years, more than half of the lakes in arid and semi-arid Central Asia have exhibited decreasing surface areas and declining water levels [5]. There have been several hazard issues that have become reality, including the shrinkage and disappearance of lake and ensuing dust storms in arid and semiarid Eurasia arid land [6-14]. A vast playa forms due to lakes shrinking or becoming desiccated. Currently, over $60,000 \mathrm{~km}^{2}$ of playa exist in Central Asia. The area of playa in the Aral Sea exceeds $30,000 \mathrm{~km}^{2}$. Ebinur Lake has become a salt desert with an area exceeding $500 \mathrm{~km}^{2}$. Lop Nur, Ayding Lake, West Juyan Lake and Qagan Lake have dried up. Frequent saline dust storms occur due to wind erosion of playas. The aforementioned lakes have become famous saline dust sources $[15,16]$.

\section{Saline dust storms}

Although not the dominant type of global dust, saline dust from playas is important with respect to atmospheric chemistry, ecological balance and human health. Most importantly, saline dust storms, which differ from common storms in the following characteristics $[15,16]$ : (1) Special dust source. The major source of dust storms in general is a natural desert (desert, bare sand, etc.) and agricultural land. However, the main sources of salt dust storms are the salt-rich deposits in dry lakebed; (2) Different chemical composition and particle size distribution. Salt dust storms contain a high density of very fine sulphates, chlorides, pesticides and heavy metals [15, 17], which causing deterioration of the ecology and environment. (3) Different transport process. Generally, transport of

\footnotetext{
* Corresponding author: jilil@ms.xjb.ac.cn
} 


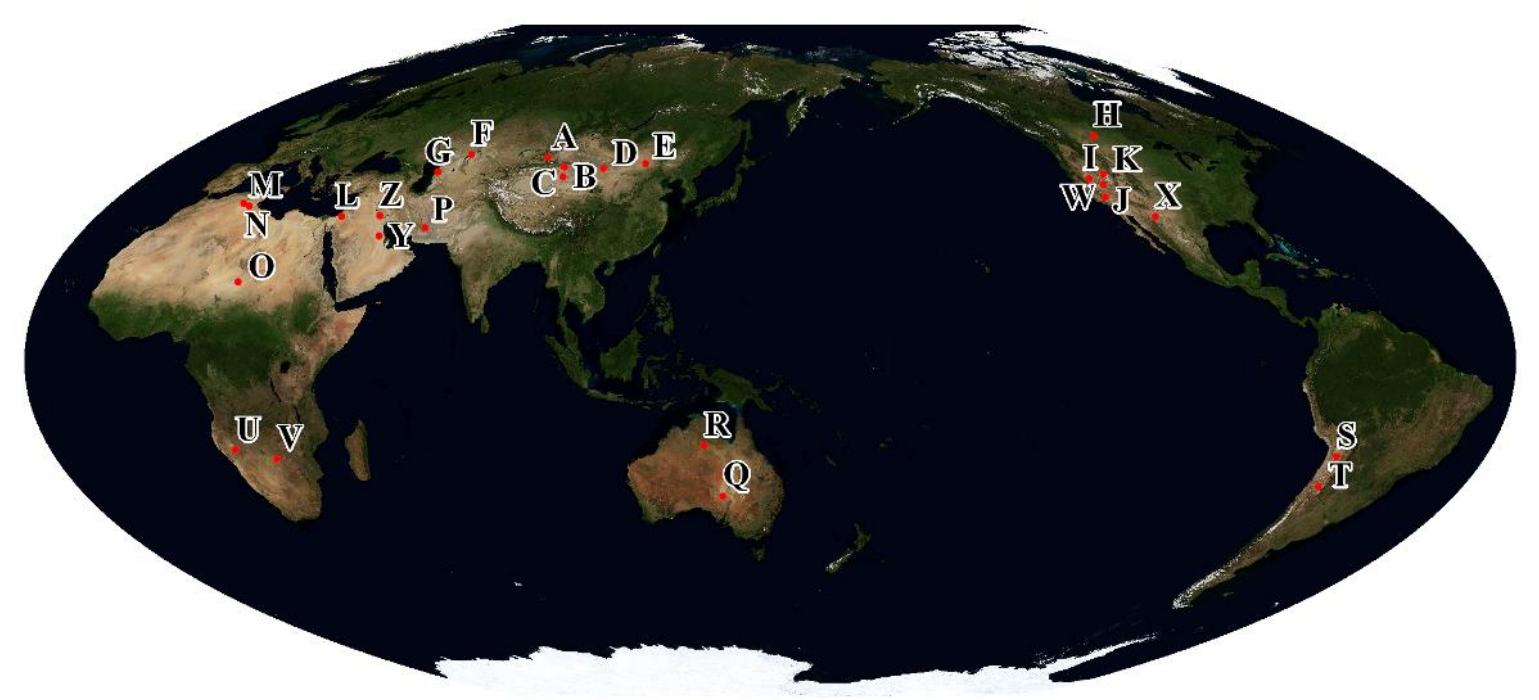

Figure 1. Distribution of the saline lakes, playas, and similar landforms in arid and semiarid lands.

Table 1. Main areas of salt dust around the world.

\begin{tabular}{clcl}
\hline Nation & Typical dust source area (Playas or sabkha) & Nation & Typical dust source area (Playas or sabkha) \\
\hline China & Ebinur Lake (A) & Chad/Nigeria & Chad Lake (O) \\
China & Lop Nur (B) & Namibia & Etosha Pan (U) \\
China & Aiding Lake (C) & Botswana & Makgadikgadi Depression (V) \\
China & Juyuan Sea (D) & Canada & Old Wives Lake (H) \\
China & Chagannuoer Lake (E) & USA & Owens Lake (I) \\
Uzbekistan & Aral Sea (F) & USA & Mojave Desert (J) \\
Kazakhstan & Kara Bogaz Gol (G) & USA & Great Basin playas (K) \\
Israel/Jordan & Dead Sea (L) & USA & Great Salt Lake (W) \\
Iraq & Seasonal salty wastelands (Z) & Mexico & Laguna Guzman (X) \\
Saudi Arabia & Persian Gulf sabkha (Y) & Bolivia & Salar de Uyani (S) \\
Iran & Hamun-i-Mashkel (P) & Argentina & Salinas Grandes (T) \\
Tunisia & Chott Jerid (M) & Australia & Lake Eyre (Q) \\
Algeria & Chott Melrhir (N) & Australia & Barkly Tableland (R)
\end{tabular}

sandstorms is basically one-way flow, while migration of salt in salt dust storm is bidirectional. Lakes in arid land, as the lowest centre of the catchment, housed chemicals from surface and underground runoff and atmospheric transport as a "sink", while also receiving a lot of sediment carried by the river. On the other hand, as the "source", output materials constantly in the form of salt dust storms. Salt dust, mainly deposit near the source region, flow into the lake again to form a loop. (4) Different hazard strength. Fine salt-rich chemical substances contained in dust storms are bigger than the dangers of storms. $\mathrm{PM}_{10}, \mathrm{PM}_{2.5}$ and other inhalable particles in salt dust storms would have a serious impact on human health $[15,16,18,19]$.

\section{Ecological and environmental impact of saline dust storms}

A lot of salt dust suspended in the atmosphere not only accelerate the melting of glacier in the Pamirs and the Tianshan Mountains, but also pose a threat to global ecological safety. These dust storms consist of fine, dense chloride, sulphate, pesticide dust, and potentially harmful metallic elements, which include arsenic, chromium, lead, and other harmful heavy metals [20]. Furthermore, $\mathrm{PM}_{10}, \mathrm{PM}_{2.5}$, and other respirable dust in saline dust storms can have serious impacts on human 
health. Due to the presence of salt dust, plants absorb significant amounts of $\mathrm{Na}^{+}$, while their ability to absorb $\mathrm{K}^{+}$is weakened, resulting in a physiological lack of $\mathrm{K}^{+}$ [21]. Frequent saline dust storms in Central Asia are not only a local issue. Many saline dust aerosols are released from the playas of Aral Sea and Garabogazkol Bay, which increases low-level cloudiness and accelerates glacial melting in the Pamirs and Tianshan Mountains. Suspended salts combined with global climate change further exacerbate the risk of snow melting in mountainous regions. People in Jinghe city and the downwind area suffer from the deterioration of the ecological environment of Ebinur Lake, where the amount of saline dustfall per square kilometer is greater than 100 tons and can be as high as 280.6 tons. These storms have resulted in a regional ecological disaster.

Saline dust storms caused break the single pattern of salt flow in arid ecosystems, and can be viewed as a redistribution of chemicals in arid and semi-arid inland lake basins. First, a tail-end lake, which acts as a sink in a basin, accumulates a variety of substances (e.g., salt, fertilizer, pesticide residues, heavy metals, and other contaminants) and many other types of fine-grained sediments brought by the surface and sub-surface runoff in the long evolution history. However, after a lake retreats, various substances in the water are gathered to the playa surface via evaporation, forming loose salt-rich deposits. Thereafter, the playa, which acts as a source, outputs a great quantity of dusts, salts, heavy metals, and other chemicals via wind erosion in a short time, forming a reverse circulation compared with water-pooled material in the basin. After being deposited in basin (mountains or oases), the various substances carried in the dust are combined in water and travel into the lake once again. Therefore, wind and water forces are intertwined and combine to create conditions that drive salinity and nutrient circulations in arid and semi-arid inland lake basins, which play an important role in the formation, development, and evolution of ecosystems and have great significance in maintaining the balance between human activities and natural processes. In the history of the earth, saline dust storms will last a long time and occupy an important historical position in the evolution of the earth, the changes of ecological environment, and the world's major pattern of desertification. Particular attention should be paid to saline dust storms in the future research of global climate change.

\section{Present state and situation}

Currently, the prevention and control measures that are implemented are mainly the diversion or conservation of water to re-cover dried lake beds to reduce wind erosion. However, the conflict between supply and demand of water resources is becoming increasingly serious and water-saving potential is limited due to continuing social and economic development in arid regions.

Moreover, evaporative losses from lake surfaces are high because of intense sunshine, large water areas, shallow water depths, and vigorous evaporation from the water surface. Therefore, the diversion or conservation of water is unsustainable. Our current understanding of the mechanism and diffusion of saline dust storms is inadequate to prevent their occurrence, particularly in arid and semi-arid land.

Recently, ecological restoration has sought to improve playa soil properties and soil-plant characteristics to enhance the nutrient supply and seedling survival rates of native species, thereby increasing the vegetation coverage of exposed lake bottoms to prevent wind erosion of salt-rich sediments and dust storm occurrences.

\section{Prospects and suggestions}

A complete understanding of the mechanism and diffusion characteristics of saline dust storms are urgently required, and control measurements are urgently needed to lessen the occurrence of saline dust storms, which has been an ignored and serious environmental issue in the context of climate change in arid and semi-arid regions.

In addition, inland lake basins should establish an integrated management system and coordination mechanism, construct digital river basins and strategically adjust the economic structure, and coordinate the relationship between human activities and natural processes.

The government must adjust the traditional narrow economic model to an ecological and green economy, transform from extensive agriculture to the ongoing development of modern intensive agriculture and improve public ecological consciousness. By following these guidelines, we can achieve regional economic development, environmental improvement, a virtuous cycle, and sustainable development, ultimately becoming a water-saving agricultural economy and society.

The release, diffusion and evolution of saline dust in arid regions should garner much more attention from scientific researchers and government of this region, addressing ecological protection and resource management in the context of climate change in arid lake basins remains a problem that must be urgently solved.

This research was funded by the National Natural Science Foundation of China $(41501115,41471098)$.

\section{References}

1. J. Abuduwaili, G. Issanova, G. Saparov, Hydrology and Limnology of Central Asia Springer Singapore (2019)

2. Z. Li, Y. Chen, W. Li, H. Deng, G. Fang, 2015. J. Geophys. Res.-Atmos. 120, 12345-12356 (2015)

3. K. M. de Beurs, G. M. Henebry, B. C. Owsley, I. N. Sokolik, Environ. Res. Lett. 13, 6 (2018)

4. J. Yao, and Y. Chen, Theor. Appl. Climatol. 120, 521-531 (2015) 
5. J. Bai, X. Chen, J. Li, L. Yang, H. Fang, Environ. Monit. Assess. 178, 247-256 (2011)

6. H. Liu, Y. Yin, S. Piao, F. Zhao, M. Engels, P. Ciais, Environ. Sci. Technol. 47, 12107-12114 (2013)

7. W. A. Wurtsbaugh, C. Miller, S. E. Null, R. J. DeRose, P. Wilcock, M. Hahnenberger, F. Howe, J. Moore, Nat. Geosci. 10, 11 (2017)

8. J. Ahmadi, D. Kahforoushan, E. Fatehifar, K. Zoroufchi Benis, M. Nadjafi, Environ. Health Eng. Manag. 3, 23-28 (2016)

9. A. Eimanifar, F. Mohebbi, Saline Systems 3, (2007)

10. A. Goudie, Desert 23, 153-164 (2018)

11. A. Gholampour, R. Nabizadeh, M. S. Hassanvand, H. Taghipour, S. Nazmara, A. H. Mahvi, J. Environ. Health Sci. Eng 13, 1-11 (2015)

12. R. Indoitu, G. Kozhoridze, M. Batyrbaeva, I. Vitkovskaya, N. Orlovsky, D. Blumberg, L. Orlovsky, Aeolian Res. 17, 101-115 (2015)

13. D. Liu, J. Abuduwaili, and L. X. Wang, Nat. Hazards 77, 1069-1080 (2015)

14. A. Rashki, D. Kaskaoutis, A. Goudie, R. Kahn, Sci. Total Environ. 463 552-564 (2013)

15. J. Abuduwaili, Lakes in Arid Land and Salt Dust Storms. China Environmental Publishing Group (2012)

16. J. Abuduwaili, L. Ma, Overview of Environment in Central Asia. China Meteorological Press, (2015)

17. D. W. Liu, J. Abuduwaili, J. Lei, G. Wu, Water Air Soil Pollut. 218, 175-184 (2011)

18. A. Goudie, Environ. Int. 63, 101-113 (2014)

19. A. Singer, T. Zobeck, L. Poberezsky, E. Argaman, J. Arid. Environ. 54, 705-728 (2003)

20. D. W. Liu, J. Abuduwaili, J. Lei, G. Wu, D. Gui, Environ. Earth Sci. 63, 241-250 (2011)

21. J. Abuduwaili, D. Liu, and G. Wu, J. of Arid Land 2, 144-150 (2010) 